THE BUSINESS OF MEDICINE

PRIVATE HEALTH CARE IN BRITAIN 


\section{Also by Joan Higgins}

The Poverty Business: Britain and America

States of Welfare: Comparative Analysis in Social Policy

Government and Urban Poverty: Inside the Policy-Making Process

(with Nicholas Deakin, John Edwards and Malcolm Wicks) 


\title{
THE BUSINESS OF MEDICINE
}

\author{
Private Health Gare in Britain
}

JOAN HIGGINS

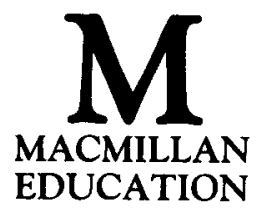




\section{(C) Joan Higgins 1988}

Softcover reprint of the hardcover 1st edition 1988

All rights reserved. No reproduction, copy or transmission of this publication may be made without written permission.

No paragraph of this publication may be reproduced, copied or transmitted save with written permission or in accordance with the provisions of the Copyright Act 1956 (as amended), or under the terms of any licence permitting limited copying issued by the Copyright Licensing Agency, 33-4 Alfred Place, London WCIE 7DP.

Any person who does any unauthorised act in relation to this publication may be liable to criminal prosecution and civil claims for damages.

First published 1988

Published by MAGMILLAN EDUCATION LTD

Houndmills, Basingstoke, Hampshire RG21 2XS and London

Companies and representatives

throughout the world

ISBN 978-0-333-45830-3

ISBN 978-1-349-19231-1 (eBook)

DOI 10.1007/978-1-349-19231-1 


\section{Contents}

Tables

vii

Acknowledgements

viii

Introduction

Definitions

Themes

The international context

$A$ personal view

1. Public and Private Medicine in the 1940s

Health services in the early twentieth century 6

Money and medicine $\quad 8$

$\begin{array}{lr}\text { Reform and the White Paper } & 13\end{array}$

$\begin{array}{ll}\text { Bevan and the Bill } & 16\end{array}$

Reactions to the Bill 19

The debate on the Bill $\quad 22$

From the Bill to the Act 24

After the Act $\quad 27$

The lessons of history $\quad 32$

2. Paying for Medicine Inside and Outside the NHS 1948-78

Outside the NHS 45

Charges, pay beds and the NHS 52

The Fourth Report from the Expenditure

Commitee, 'National Health Service

Facilities for Private Patients' 60

Barbara Castle and the pay beds dispute $\quad 63$

The Health Services Board 70

The impact of the pay beds dispute $\quad 72$ 


\section{The Boom Years: The Private Market After}

\section{9}

Changes in Government policy

Private insurance: boom and bust?

Hospitals and beds

The disappearing overseas patients

Diversification of the market

How is private medicine doing?

4. A Taste of American Medicine

American for-profit corporations: who they are and what they do

American medicine in America

Over-ambitious, over-bedded and over here: opposition to American corporations in Britain

The medical-industrial complex

\section{Winners and Losers}

Who are the private patients?

Why do patients 'go private'?

Who benefits from the private sector?

Calculating the losses

6. Trends and Issues in the Private Sector

Is small beautiful?

Two tiers or many?

Consumers and the health care market

Doctors, patients and money

The problem of equity

\section{Conclusions}

The significance of changes in the private market

The lessons for the NHS

Value for money

Morality and the Market 


\section{Tables}

2.1 The provident population: persons insured, number of subscribers and net change (BUPA, PPP and WPA), 1950-77

3.1 Breakdown of subscriber by purchase category (BUPA, PPP and WPA), 1977-83

3.2 Authorised pay beds in NHS hospitals in England, Wales and Scotland 1974-83 


\section{Acknowledgements}

This book would never have reached completion without the support of a number of organisations and individuals.

I am particularly indebted to the Economic and Social Research Council for awarding me a Personal Research Grant (G 0024 2023) in 1985-6, and to my colleagues at the University of Southampton who enabled me to take a year's leave to write the book. The Department of Sociology and Social Administration also provided me with financial support which was much appreciated. This enabled me to employ two research assistants, Fiona Bower and Mary Thomas, to help with the bibliographical work and piles of press cuttings. Linda Hull also gave me valuable help.

I am grateful to the many people in the private sector who so readily showed me their facilities and talked about their work. John Randle of the Association of Independent Hospitals was especially helpful in supplying statistics on changes in the private market.

Numerous other people, including Barbara Castle, MEP, discussed a wide range of relevant topics which filled gaps in my knowledge or allowed me to check ideas with their experience.

I have benefited greatly from the critical comments of colleagues on the occasions when I have talked about sections of the book and from those of anonymous readers who saw a draft of the manuscript. Steven Kennedy from Macmillan gave constructive editorial advice.

Special thanks go to Tony Rees and John Martin who read the manuscript very carefully and made detailed suggestions. I am sure the finished product - with all its flaws - is an improvement on the original, as a result of their advice. John Martin encouraged me in the research from the beginning and I am very grateful for his support.

The typing services provided by Veronica Jones Associates 
were extremely fast and efficient and a good advertisement for private enterprise!

My final acknowledgement is also a sort of dedication and a wish for the future. I have always felt a profound commitment to the National Health Service and to the values it represents. I was born just 21 days before it came into being and was one of its first customers for 'free' services. My parents both worked in it all their lives. I share the view of Richard Titmuss that its creation was 'the most unsordid act of British social policy in the twentieth century' (1973, p. 254). This book is written for all the people who have worked in the NHS (especially my parents and friends) and all who have benefited from its services. I trust that the developments described in these pages will never weaken the principles upon which the Service was founded and that the generation which saw its flowering will not see its demise. 